\title{
Phenotypic parameters of macromineral and phenolic compound concentrations and selection of Andean bean lines with nutritional and functional properties
}

\section{Parâmetros fenotípicos da concentração de macrominerais e compostos fenólicos e seleção de linhagens de feijão Andino com propriedades nutricionais e funcionais}

\author{
Nerinéia Dalfollo Ribeiro ${ }^{1 *} \mathbb{C}$, Henrique Caletti Mezzomo ${ }^{1}$
}

'Universidade Federal de Santa Maria/UFSM, Departamento de Fitotecnia, Santa Maria, RS, Brasil

${ }^{*}$ Corresponding author: nerineia@hotmail.com

Received in January 7, 2020 and approved in April 1, 2020

\begin{abstract}
The development of Andean common bean lines that contain high macromineral concentration and a phenolic compound concentration that meets the consumer's dietary requirements is unprecedented in the literature. The objectives of this study were to obtain estimates of phenotypic parameters for the macromineral and phenolic compound concentrations in a recombinant inbred line (RIL) population of Andean beans and to select lines with nutritional and functional properties. The RIL was obtained from a cross between cultivars Hooter and $\mathrm{Cal}$ 96. The lines in the $F_{5: 6}$ and $F_{5: 7}$ generations and the cultivars were evaluated in two consecutive experiments in the same experimental area. The concentrations of potassium (K), phosphorus $(\mathrm{P})$, magnesium $(\mathrm{Mg})$, and calcium (Ca) were determined by acid digestion, whereas the phenolic compound concentration was obtained by the Follin-Ciocalteu method. A significant genotype effect was observed for all traits evaluated in the $F_{5: 6}$ and $F_{5: 7}$ generations. Intermediate-to-high heritability estimates ( $h{ }^{2}: 43.15$ to $98.85 \%$ ) were obtained for the concentrations of $\mathrm{K}, \mathrm{P}, \mathrm{Mg}, \mathrm{Ca}$ and phenolic compounds. These traits exhibited transgressive segregation and quantitative inheritance in the RIL population of Andean beans. Lines DFA 34-18 and DFA 46-18 have high K and P concentrations and low phenolic compound concentration and will be selected by the human nutrition. Lines DFA 04-18 and DFA 05-18 and cultivars Pérola, IPR Siriri, IAC Imperador, and IPR Tangará showed high concentrations of two or more macrominerals and phenolic compounds; therefore, they have nutritional and functional properties and will be selected by the breeding program.
\end{abstract}

Index terms: Phaseolus vulgaris; heritability; inheritance pattern; selection index.

\begin{abstract}
RESUMO
O desenvolvimento de linhagens de feijão Andino com alta concentração de macrominerais e com concentração de compostos fenólicos que atenda às necessidades da dieta do consumidor é inédito na literatura. Os objetivos desse trabalho foram obter estimativas de parâmetros fenotípicos para a concentração de macrominerais e compostos fenólicos em uma população de linhagens recombinantes (LR) de feijão Andino e selecionar linhagens com propriedades nutricionais e funcionais. As LR foram obtidas a partir do cruzamento entre as cultivares Hooter e Cal 96. As linhagens em geração $F_{5: 6}$ e $F_{5: 7}$ e as cultivares foram avaliadas em dois experimentos consecutivos na mesma área experimental. A concentração de $\mathrm{K}, \mathrm{P}, \mathrm{Mg}$ and $\mathrm{Ca}$ foi determinada por digestão ácida e a concentração de compostos fenólicos foi obtida pelo método de Follin-Ciocalteu. Efeito significativo para genótipo foi observado para todos os caracteres avaliados nas gerações $F_{5: 6}$ e $F_{5: 7}$. Herdabilidade de intermediaria a alta magnitude ( $\mathrm{h}^{2}: 43,15$ a 98,85\%) foi verificada para a concentração de K, P, Mg, Ca e compostos fenólicos. Esses caracteres apresentaram segregação transgressiva e herança quantitativa na população de LR de feijão Andino. As linhagens DFA 34-18 e DFA 46-18 possuem alta concentração de K e P e baixa concentração de compostos fenólicos e serão selecionadas para a nutrição humana. As linhagens DFA 04-18 e DFA 05-18 e as cultivares Pérola, IPR Siriri, IAC Imperador e IPR Tangará apresentam alta concentração de dois ou mais macrominerais e de compostos fenólicos, portanto têm propriedades nutricionais e funcionais e serão selecionadas pelo programa de melhoramento.
\end{abstract}

Termos para indexação: Phaseolus vulgaris; herdabilidade; padrão de herança; índice de seleção.

\section{INTRODUCTION}

Common bean (Phaseolus vulgaris) is an excellent source of minerals (Silva et al., 2012; Hossain et al., 2013) and bioactive compounds such as phenolic compounds, phytates, among others (Chávez-Mendoza; Sánchez, 2017; Ganesan; Xu, 2017; García-Díaz et al., 2018). The existing genetic variability in the mineral (Silva et al., 2012; Zilio; Souza; Coelho, 2017) and phenolic compound (Santos et al., 2010; Marathe et al., 2011) 
concentrations in common bean increases the chances of success in breeding for nutritional quality.

Common-bean breeding programs have put great effort into iron and zinc biofortification, since deficiencies of these minerals are the most common and prevalent in several countries. However, increase macromineral concentrations in common bean may offer various benefits to health, e.g., $\mathrm{K}$ contributes to reducing the risk of hypertension (Ekmekciouglu et al., 2016); P is required for the maintenance of bones and teeth (Pravst, 2011); $\mathrm{Mg}$ helps prevent cardiovascular disease (Alawi; Majoni; Falhammar, 2018) and $\mathrm{Ca}$ is important in reducing the occurrence of fractures and osteoporosis (Wimalawansa; Razzaque; Al-Daghri, 2018). These macrominerals are found in large quantities in common bean (Silva et al., 2012; Hossain et al., 2013).

For many years, the breeding of common bean for improved nutritional quality was based on increasing mineral concentrations. However, the phenolic compounds present in the grain may act as an anti-nutritional factor, reducing the digestion of this food (Ganesan; Xu, 2017). Thus, when a common-bean breeding program aims at the development of cultivars for human nutrition, these should include high mineral concentrations and low phenolic compound concentration. Those cultivars are indicated for diets made up essentially of cereals and legumes. Conversely, if the goal of a breeding program is to release common bean cultivars with nutritional and functional properties, the cultivars should have high mineral and phenolic compound concentrations. These cultivars are indicated for diets containing a diversity of plant- and animal-based foods so that the consumer can benefit from the anti-oxidant and cardioprotective effects of phenolic compounds (Chávez-Mendoza; Sánchez, 2017; Ganesan; Xu, 2017). The development of common bean lines with high macromineral concentrations and phenolic compound concentration that meets the consumer's dietary requirements is unprecedented in the literature.

Common bean lines with high macromineral concentrations in the grains have been obtained by classical breeding (Jost et al., 2013; Maziero; Ribeiro; Facco, 2016; Ribeiro; Mezzomo; dos Santos, 2019; Ribeiro et al., 2019). In these works, heritability estimates were mostly of intermediate to high magnitude for the concentrations of $\mathrm{K}, \mathrm{P}, \mathrm{Mg}$ and $\mathrm{Ca}$, which allows for genetic progress. These studies are, however, restricted to Mesoamerican beans, involving the grain types most widely consumed in Brazil, the carioca beans (beige seed coat and brown streaks) and the black beans. No previous studies have been found on estimates of genetic parameters of macromineral and phenolic compound concentrations in Andean common bean for segregating or highly homozygous populations obtained by breeding.

Of the many types of Andean common bean produced in Brazil, cranberry beans (cream seed coat with red streaks and patches) and red mottled beans (red seed coat with cream streaks) are highly appreciated for consumption in the states of Rio Grande do Sul, Santa Catarina, Paraná, Minas Gerais and São Paulo. There is also a high demand for cranberry and red mottled beans in the international market, especially in France, Italy, Spain, Germany and Portugal (Ferrari; Ramos Júnior, 2015). Therefore, the development of new cultivars of cranberry and red mottled beans represents technological advances. If these cultivars have nutritional quality to meet the different nutritional needs of consumers, they can contribute to improving human nutrition and health. To the present date, no breeding programs have been proposed the development of Andean common bean cultivars with nutritional and functional properties. In this scenario, the present study was undertaken to obtain estimates of phenotypic parameters for the macromineral and phenolic compound concentrations in a recombinant inbred line population of Andean common bean and to select lines with nutritional and functional properties.

\section{MATERIAL AND METHODS}

\section{Production of the Andean common bean lines}

Andean common bean lines were obtained at the Federal University of Santa Maria (UFSM), from a biparental cross between cultivars Hooter and Cal 96. Cultivar Hooter has cranberry beans (light cream seed coat with red streaks and patches) and was released in the USA by the Seminis Seed Company in 2009. Cultivar Cal 96 has red mottled beans (dark red seed coat with cream streaks) and was registered in Uganda by the National Agricultural Research Organization in 1998. These cultivars were selected due to their adaptation to the cultivation conditions found in the Southern region of Brazil (Ribeiro et al., 2014a) and their contrasting difference in $\mathrm{K}$ and $\mathrm{Ca}$ concentrations in the grains (Ribeiro et al., 2014b).

Crosses were performed in 2012, in a greenhouse. The obtained recombinants were advanced up to the $F_{5}$ generation by the Single-Seed Descent method. However, three seeds were sown per progeny in each pot, which was thinned to one plant per progeny at the first trifoliate leaf stage to prevent loss of genetic variability due to germination problems. The seeds obtained of each $\mathrm{F}_{5}$ 
plant were harvested individually and packed in paper bags. Only the plants that exhibited a sufficient number of seeds for the development of a field experiment were evaluated. Each $\mathrm{F}_{5}$ plant generated was considered a RIL.

\section{Experiments for the assessment of the Andean common bean lines}

The experiments were carried out in an area of the Department of Plant Sciences at UFSM, in Santa Maria, Rio Grande do Sul (RS), Brazil (29 $42^{\prime}$ south latitude, $53^{\circ} 43^{\prime}$ west longitude, and at $95 \mathrm{~m}$ above sea level). Santa Maria has a humid subtropical climate, with hot summers and no clearly defined dry season (Kuinchtner; Buriol, 2001). The soil in the experimental area is a typical alitic Argisol, Hapludalf (Santos et al., 2018), which was cultivated in a bean-bean-oat succession system under conventional soil preparation practices.

The first experiment was established in the as a rainy-season crop of 2017, with the cultivation taking place between October 2017 and January 2018, as an augmented block design, with three replications. Treatments consisted of 61 common bean genotypes, represented by 57 lines of Andean common bean in the $\mathrm{F}_{5: 6}$ generation, two parental cultivars (Hooter and Cal 96) and two control cultivars (Pérola and Iraí). The lines were evaluated once throughout the experiment (regular treatments), and the parental and control cultivars were included in the three replications (common treatments). In the analysis of variance, the means of regular treatment were adjusted in relation to the blocks.

The second experiment was implemented as a dry-season crop of 2018 (cultivation between February and June 2018), in an $8 \times 8$ simple lattice design, with two replications. This experiment involved 64 common bean genotypes, consisting of 52 lines of Andean common bean in the $\mathrm{F}_{5.7}$ generation, two parental cultivars (Hooter and Cal 96) and 10 common bean cultivars (controls: Iraí, BRS MG Realce, Pérola, Carioca, BRS Estilo, Fepagro Garapiá, IAC Imperador, IPR Tangará, IPR Siriri and SCS Riqueza). Iraí and BRS MG Realce are the only Andean common bean cultivars registered for cultivation in RS state. The other common bean cultivars used as control belong to the Mesoamerican gene pool, and have carioca beans (beige seed coat with brown streaks), which are the most widely grown and consumed grain type in Brazil.

In both experiments, the experimental plot was composed of a $1 \mathrm{~m}$ row, spaced at $0.5 \mathrm{~m}$. The adopted sowing density was 15 seeds per linear meter. The management practices consisted of fertilization, seed treatment with fungicide and insecticide, application of pre-emergence herbicide, mechanical weed control and chemical insect control, which were performed in accordance with the technical recommendations for the common bean crop in RS state (Ctsbf, 2012).

The bean plants were harvested manually at maturation, i.e., when the pods lost pigmentation and the grains acquired the typical color of each genotype (R9 stage). The grains were threshed without the use of agricultural machinery, to prevent samples contamination. Grain moisture was measured using a portable moisture meter and standardized to $13 \%$. When necessary, the grains were oven-dried at $40{ }^{\circ} \mathrm{C}$.

\section{Determination of nutritional and functional properties}

A $10 \mathrm{~g}$ grain sample was collected at random from each experimental unit. These raw grain samples were ground in a micro-mill until a homogeneous fine powder was obtained. A $0.5 \mathrm{~g}$ subsample of the obtained flour was used to determine the mineral concentrations and a $0.2 \mathrm{~g}$ subsample was used to extract the phenolic compounds.

Acid digestion was performed as described by Miyazawa et al. (2009) for the extraction of minerals from plant tissues. The obtained extract was placed in $50 \mathrm{~mL}$ Falcon tubes, and then the recommended dilutions for the $\mathrm{K}, \mathrm{P}, \mathrm{Mg}$, and $\mathrm{Ca}$ readings were realized. The following equipments were used for the mineral readings: flame photometer $(\mathrm{K})$, optical emission spectrophotometer $(\mathrm{P})$ and atomic absorption spectrophotometer ( $\mathrm{Mg}$ and $\mathrm{Ca}$ ). The obtained results were expressed in grams per kilogram of dry matter $\left(\mathrm{g} \mathrm{kg}^{-1} \mathrm{DM}\right)$.

The phenolic compounds were determined by the Folin-Ciocalteu method, described by Singleton and Rossi Júnior (1965). The phenolic compounds were read using a UV-Vis reader and microplate fluorescence, at a wavelength of $765 \mathrm{~nm}$. A standard curve was generated with gallic acid and the phenolic compound concentration was expressed as milligrams of gallic acid equivalent per gram of dry matter (mg GAE g-1 DM).

\section{Statistical analysis}

Data obtained from the $\mathrm{F}_{5: 6}$ generation were subjected to analysis of variance in an augmented block design, whereas the data obtained from the $\mathrm{F}_{5: 7}$ generation were analyzed as a simple lattice design. In the second experiment, we evaluated the efficiency of the lattice design in relation to the randomized block design, as recommended by Ramalho, Ferreira and Oliveira (2000).

The phenotypic parameters were estimated for the two evaluated generations. The coefficient of experimental variation (CEV) and selective accuracy (SA) were adopted 
as statistical parameters to evaluate the experimental precision of the evaluated traits. The CEV was obtained by the following formula: $\mathrm{CEV}=100 \frac{\sqrt{\mathrm{EMS}}}{\mathrm{m}}$, where EMS corresponds to the error mean square and $\mathrm{m}$ is the overall mean of the experiment. The SA was calculated by the following expression: $\mathrm{SA}=\sqrt{1-\frac{1}{\mathrm{Fc}}}$, where $\mathrm{Fc}$ stands for the

F-test value for genotype calculated in the analysis of variance.

The heritability $\left(\mathrm{h}^{2}\right)$, coefficient of genetic variation $(\mathrm{CGV})$, and $\mathrm{b}$ coefficient estimates were used for the analysis of the genetic parameters of the analyzed population of common bean. The $\mathrm{h}^{2}$ was estimated considering the mean of the genotypes, using the formula: $h^{2}=\frac{\sigma^{2} \mathrm{G}}{\sigma^{2} \mathrm{P}}$, where $\sigma^{2} \mathrm{G}$ is the genetic variance and $\sigma^{2} \mathrm{P}$ is the phenotypic variance. Because genetic variance corresponds to the additive variance in highly homozygous generations $\left(\mathrm{F}_{5: 6}\right.$ and $\left.\mathrm{F}_{5: 7}\right)$, the obtained heritability estimates corresponds to the narrow sense heritability. The CGV was obtained by the following expression: $\mathrm{CGV}=100 \frac{\sqrt{G M S}}{\mathrm{~m}}$, where GMS corresponds to the genotype mean square and $\mathrm{m}$ is the overall mean of the experiment. The $\mathrm{b}$ coefficient was estimated as the ratio between CGV/CEV.

Data normality was checked by the Lilliefors test, adopting the $5 \%$ probability level. The inheritance pattern was analyzed based on the frequency distribution of the values obtained for each trait in the $\mathrm{F}_{5: 6}$ and $\mathrm{F}_{5: 7}$ generations. To this end, frequency distribution histograms were constructed in which the number of classes was defined by the expression $\sqrt{n}$, where $\mathrm{n}=$ number of observations.

The index based on the rank sum (Mulamba; Mock, 1978) was used to obtained estimates of genetic gain and to select the superior Andean common bean genotypes. For this purpose, the applied selection intensity was $20 \%$, which resulted in the selection of 13 genotypes with nutritional properties (scenario 1) and 13 genotypes with nutritional and functional properties (scenario 2). For scenario 1, the selection was performed to increase the concentrations of $\mathrm{K}, \mathrm{P}, \mathrm{Mg}$, and $\mathrm{Ca}$, in which weight 2 was attributed to these traits and decrease the phenolic compound concentration (weight 1). For scenario 2, direct selection was applied for all traits, with weight 1 being attributed to the concentrations of $\mathrm{K}, \mathrm{Mg}$, and $\mathrm{Ca}$, whereas weight 2 was given to the $P$ concentration, and weight 3 was attributed to the phenolic compound concentration. Analyses were performed using a Microsoft Office Excel spreadsheet and the Genes software (Cruz, 2016).

\section{RESULTS AND DISCUSSION}

\section{Analysis of variance}

A significant difference for genotype ( $\mathrm{P}$ value $<$ 0.05 ) was detected for all the traits evaluated in the $\mathrm{F}_{5: 6}$ and $\mathrm{F}_{5: 7}$ generations (Table 1). Therefore, the Andean common bean lines obtained from the cross between cultivars Hooter and $\mathrm{Cal} 96$ showed variations in the concentrations of $\mathrm{K}, \mathrm{P}, \mathrm{Mg}, \mathrm{Ca}$, and phenolic compounds, allowing the selection of lines with nutritional and functional properties. Previous results have shown that it is possible to obtain common bean lines with wide genetic variability for $\mathrm{P}$ (Blair et al., 2009, 2012), Ca and Mg (Casañas et al., 2013) from crosses between Andean and Mesoamerican common bean genotypes. However, there are no records of studies aiming at the development of Andean common bean lines with high macromineral concentration and a phenolic compound concentration that meets the different nutritional requirements of human diets. Therefore, the present study is unique in the literature.

Coefficients of experimental variation lower than $21.09 \%$ and selective accuracy values ranging from 0.66 to 0.99 were obtained for the macromineral and phenolic compound concentrations. Higher coefficient of experimental variation values were observed for the $\mathrm{K}$ and $\mathrm{P}$ concentrations determined in Andean and Mesoamerican common bean genotypes by Zilio, Souza and Coelho (2017). García-Díaz et al. (2018), in turn, found lower coefficient of experimental variation values for the phenolic compound concentration evaluated in native bean populations from Mexico. On the other hand, the macromineral concentration determined in common bean genotypes of different grain classes showed selective accuracy $\geq 0.94$ (Silva et al., 2012). In the present study, the use of the augmented block design in the $\mathrm{F}_{5: 6}$ generation and simple lattice in the $F_{5.7}$ generation allowed for an evaluation of nutritional and functional traits of Andean beans with high experimental precision, considering coefficient of experimental variation. The selective accuracy indicated that experimental precision was from intermediate to high (selective accuracy $\geq 0.66$ ), according to the classification proposed by Resende and Duarte (2007). In the $F_{5: 7}$ generation, the use of the simple lattice design revealed over $100 \%$ efficiency for all traits, except for the phenolic compound concentration. Therefore, the use of the simple lattice design was suitable for most of the evaluated traits, and the analysis of variance in lattice design was maintained, as recommended by Ramalho, Ferreira and Oliveira (2000). 
Table 1: Analysis of variance and estimates of phenotypic parameters for the concentrations of potassium ( $K$, $\mathrm{g} \mathrm{kg}^{-1}$ of dry matter - DM), phosphorus ( $\left.\mathrm{P}, \mathrm{g} \mathrm{kg}^{-1} \mathrm{DM}\right)$, magnesium ( $\left.\mathrm{Mg}, \mathrm{g} \mathrm{kg}^{-1} \mathrm{DM}\right)$, calcium (Ca, $\left.\mathrm{g} \mathrm{kg}^{-1} \mathrm{DM}\right)$, and phenolic compounds ( $P C$, mg of gallic acid equivalent per $g$ of $D M$ ) obtained in the Andean common bean lines in the $F_{5: 6}$ and $F_{5: 7}$ generations.

\begin{tabular}{|c|c|c|c|c|c|c|}
\hline \multirow[t]{2}{*}{ Sources of variation } & \multirow[t]{2}{*}{ DF } & \multicolumn{5}{|c|}{ Mean square } \\
\hline & & K & $\mathrm{P}$ & $\mathrm{Mg}$ & $\mathrm{Ca}$ & PC \\
\hline & \multicolumn{5}{|c|}{$F_{5: 6}$ generation } & \\
\hline Block & 2 & 2.01 & 0.81 & 0.00 & 0.18 & 1.08 \\
\hline Genotype (adjusted) & 60 & $1.28^{*}$ & $0.19^{*}$ & $0.01^{*}$ & $0.12^{*}$ & $0.59^{*}$ \\
\hline Residue & 6 & 0.18 & 0.03 & 0.00 & 0.02 & 0.15 \\
\hline CEV $(\%)^{1}$ & & 3.72 & 4.46 & 0.50 & 12.24 & 9.66 \\
\hline Selective accuracy & & 0.93 & 0.91 & 0.99 & 0.92 & 0.86 \\
\hline General mean & & 11.41 & 3.96 & 1.83 & 1.11 & 3.92 \\
\hline Lines mean & & 11.44 & 4.08 & 1.84 & 1.10 & 4.00 \\
\hline Control mean & & 11.23 & 3.96 & 1.82 & 1.14 & 3.57 \\
\hline Phenotypic variance & & 1.382 & 0.200 & 0.007 & 0.100 & 0.704 \\
\hline Environmental variance & & 0.181 & 0.033 & 0.000 & 0.018 & 0.149 \\
\hline Genetic variance & & 1.201 & 0.166 & 0.007 & 0.082 & 0.555 \\
\hline Heritability (\%) & & 86.90 & 83.42 & 98.85 & 81.85 & 78.83 \\
\hline CGV $(\%)^{2}$ & & 9.58 & 10.00 & 4.61 & 25.99 & 18.64 \\
\hline \multirow[t]{2}{*}{ Coefficient $b^{3}$} & & 2.57 & 2.24 & 9.28 & 2.12 & 1.93 \\
\hline & \multicolumn{5}{|c|}{$\mathrm{F}_{5: 7}$ generation } & \\
\hline Replication & 1 & 1.44 & 1.75 & 0.00 & 0.00 & 1.08 \\
\hline Block/replication (adjusted) & 14 & 0.58 & 0.19 & 6.71 & 1.68 & 0.20 \\
\hline Genotype (adjusted) & 63 & $0.61^{*}$ & $0.20^{*}$ & $0.01^{*}$ & $0.09^{*}$ & $1.16^{*}$ \\
\hline Residue & 49 & 0.33 & 0.12 & 0.00 & 0.01 & 0.34 \\
\hline CEV $(\%)^{1}$ & & 4.19 & 7.14 & 3.10 & 11.87 & 21.09 \\
\hline Selective accuracy & & 0.67 & 0.66 & 0.83 & 0.92 & 0.84 \\
\hline Lattice efficiency (\%) & & 109.09 & 106.63 & 116.24 & 101.92 & 90.76 \\
\hline General mean & & 13.78 & 4.77 & 1.81 & 0.97 & 2.78 \\
\hline Lines mean & & 13.77 & 4.79 & 1.81 & 0.92 & 2.81 \\
\hline Control mean & & 13.74 & 4.70 & 1.80 & 1.16 & 2.64 \\
\hline Phenotypic variance & & 0.307 & 0.102 & 0.005 & 0.046 & 0.583 \\
\hline Environmental variance & & 0.167 & 0.058 & 0.002 & 0.007 & 0.172 \\
\hline Genetic variance & & 0.140 & 0.044 & 0.003 & 0.039 & 0.411 \\
\hline Heritability (\%) & & 45.71 & 43.15 & 69.01 & 85.67 & 70.51 \\
\hline CGV $(\%)^{2}$ & & 2.72 & 4.40 & 3.27 & 20.51 & 23.06 \\
\hline Coefficient $b^{3}$ & & 0.65 & 0.62 & 1.05 & 1.73 & 1.09 \\
\hline
\end{tabular}

${ }^{1} \mathrm{CEV}(\%)$ : coefficient of environmental variation. ${ }^{2} \mathrm{CGV}(\%)$ : coefficient of genetic variation. ${ }^{3}$ Coefficient b: $\mathrm{CVg} / \mathrm{CVe}$ ratio. "Significant by $\mathrm{F}$ test at 0.05 probability. 


\section{Genetic parameters}

The heritability of the concentrations of $\mathrm{K}, \mathrm{P}, \mathrm{Mg}, \mathrm{Ca}$, and phenolic compounds in Andean beans ranged from 78.83 to $98.85 \%$ in the $\mathrm{F}_{5: 6}$ generation and from 43.15 to $85.67 \%$ in the $\mathrm{F}_{5: 7}$ generation (Table 1), characterizing it as of intermediate to high magnitude, according to the classes proposed by Soltani et al. (2016). Similarly, Katuuramuru et al. (2018) observed intermediate heritability for the concentrations of K, $\mathrm{P}$ and $\mathrm{Ca}$ in cooked grains of 206 genotypes of Andean beans from different countries and evaluated in the USA. Estimates of genetic parameters for macromineral and phenolic compound concentrations obtained in segregating or highly homozygous populations by classical breeding methods are unprecedented in Andean beans.

However, heritability for the macromineral concentration has been studied in recombinant inbred line populations of Mesoamerican beans. The concentrations of $\mathrm{K}, \mathrm{Mg}$, and $\mathrm{Ca}$ exhibited intermediate to high heritability (Ribeiro; Mezzomo; dos Santos, 2019), whereas the P concentration showed low to high heritability (Ribeiro et al., 2019) in a recombinant inbred line population of Mesoamerican common bean in the $\mathrm{F}_{5: 6}$ and $\mathrm{F}_{5: 7}$ generations. High heritability was observed for the $\mathrm{Ca}$ concentration in $272 \mathrm{~F}_{7}$ lines of Mesoamerican common bean (Jost et al., 2013) and low to high heritability was found for the $\mathrm{K}$ and $\mathrm{P}$ concentrations in four recombinant inbred line populations in an $\mathrm{F}_{6: 8}$ generation of Mesoamerican common bean (Maziero; Ribeiro; Facco, 2016). The concentrations of $\mathrm{K}, \mathrm{P}, \mathrm{Mg}$ and $\mathrm{Ca}$ showed high heritability $\left(\mathrm{h}^{2} \geq 78.80 \%\right)$ in 277 inbred lines of Mesoamerican beans evaluated in the USA (McClean et al., 2017). These results demonstrate that heritability for macrominerals in common bean varies according to the population, generation, and between gene pools. No heritability estimates for the phenolic compound concentration were found in the literature for common bean and other legumes such as soybean and cowpea.

Traits of intermediate to high heritability are promising in a breeding program, since they allow for genetic progress to be achieved. Higher heritability estimates mean greater chances of success in the selection of Andean bean lines with high macromineral concentration and a phenolic compound concentration that meets the consumer's dietary requirements.

In this study, the coefficient of genetic variation ranged from 2.72 to $25.99 \%$, indicating a greatest contribution of the genetic variation on the expression of the concentrations of $\mathrm{K}, \mathrm{P}, \mathrm{Mg}, \mathrm{Ca}$, and phenolic compounds in Andean beans. No previous studies have been found in the literature examining coefficient of genetic variation for those traits in Andean beans. In Mesoamerican beans, similar coefficient of genetic variation values were obtained for the Ca concentration (Jost et al., 2013) and for the K and P concentrations (Maziero; Ribeiro; Facco, 2016) in inbred lines. However, higher coefficient of genetic variation values were reported for the $\mathrm{P}$ concentration (Ribeiro et al., 2019) and for the concentrations of $\mathrm{K}, \mathrm{Mg}$, and $\mathrm{Ca}$ (Ribeiro; Mezzomo; dos Santos, 2019) in a recombinant inbred line population of Mesoamerican common bean. High coefficient of genetic variation values were obtained in the present study for the macromineral and phenolic compound concentrations in Andean beans, suggesting favorable aspects for selection due to lesser environmental interference in the manifestation of those traits.

All traits showed b coefficients $\geq 1.0$, except for the $\mathrm{K}$ and $\mathrm{P}$ concentrations in the $\mathrm{F}_{5: 7}$ generation. The $\mathrm{b}$ coefficient estimates confirmed that the genetic variability obtained for the $\mathrm{K}$ and $\mathrm{P}$ concentrations was lower (lower $\mathrm{h}^{2}$ values) in the $\mathrm{F}_{5: 7}$ generation. Coefficients $\geq 1.0$ indicate greater genetic variability between the Andean common bean lines for the concentrations of $\mathrm{Mg}, \mathrm{Ca}$, and phenolic compounds in the two evaluated generations and for the $\mathrm{K}$ and $\mathrm{P}$ concentrations in the $\mathrm{F}_{5: 6}$ generation, which, according to Vencovsky and Barriga (1992), characterizes a very favorable situation for selection.

The magnitude of the obtained estimates of genetic parameters $\left(\mathrm{h}^{2}, \mathrm{CGV}\right.$ and $\mathrm{b}$ coefficient) revealed that the Andean common bean lines showed genetic variability for the concentrations of $\mathrm{K}, \mathrm{P}, \mathrm{Mg}, \mathrm{Ca}$, and phenolic compounds. This enables the selection of superior lines and the release of Andean common bean cultivars with nutritional and functional properties.

\section{Inheritance pattern of macromineral and phenolic compound concentrations}

The values of $\mathrm{K}, \mathrm{P}, \mathrm{Mg}, \mathrm{Ca}$, and phenolic compounds showed a normal distribution close to the mean in both generations, according to the Lilliefors test. The frequency distribution histograms indicated a quantitative inheritance pattern for all traits evaluated in Andean beans (Figures 1A, 1B, 1C, 1D, 1E, 1F, 1G, 1H, 1I, and 1J). Quantitative inheritance had been previously reported for the $P$ concentration in recombinant inbred line populations obtained from a cross between Andean and Mesoamerican bean lines in the $\mathrm{F}_{5: 8}$ (Blair et al., 2009) and $\mathrm{F}_{7: 11}$ (Blair et al., 2012) generations. Similarly, quantitative inheritance was observed for the $\mathrm{Mg}$ and $\mathrm{Ca}$ concentrations evaluated in 104 inbred lines obtained from a cross between Andean and Mesoamerican parents (Casañas et al., 2013). In cooked grains of 206 genotypes of Andean beans, it was 
also observed that the concentrations of $\mathrm{K}, \mathrm{Ca}$, and $\mathrm{P}$ exhibited quantitative inheritance, with the possibility of multiple loci being involved in the absorption and accumulation of those minerals in the grains (Katuuramu et al., 2018). No previous articles have been found analyzing the inheritance pattern of phenolic compound concentration in Andean or Mesoamerican beans, in a segregation or highly homozygous generation.
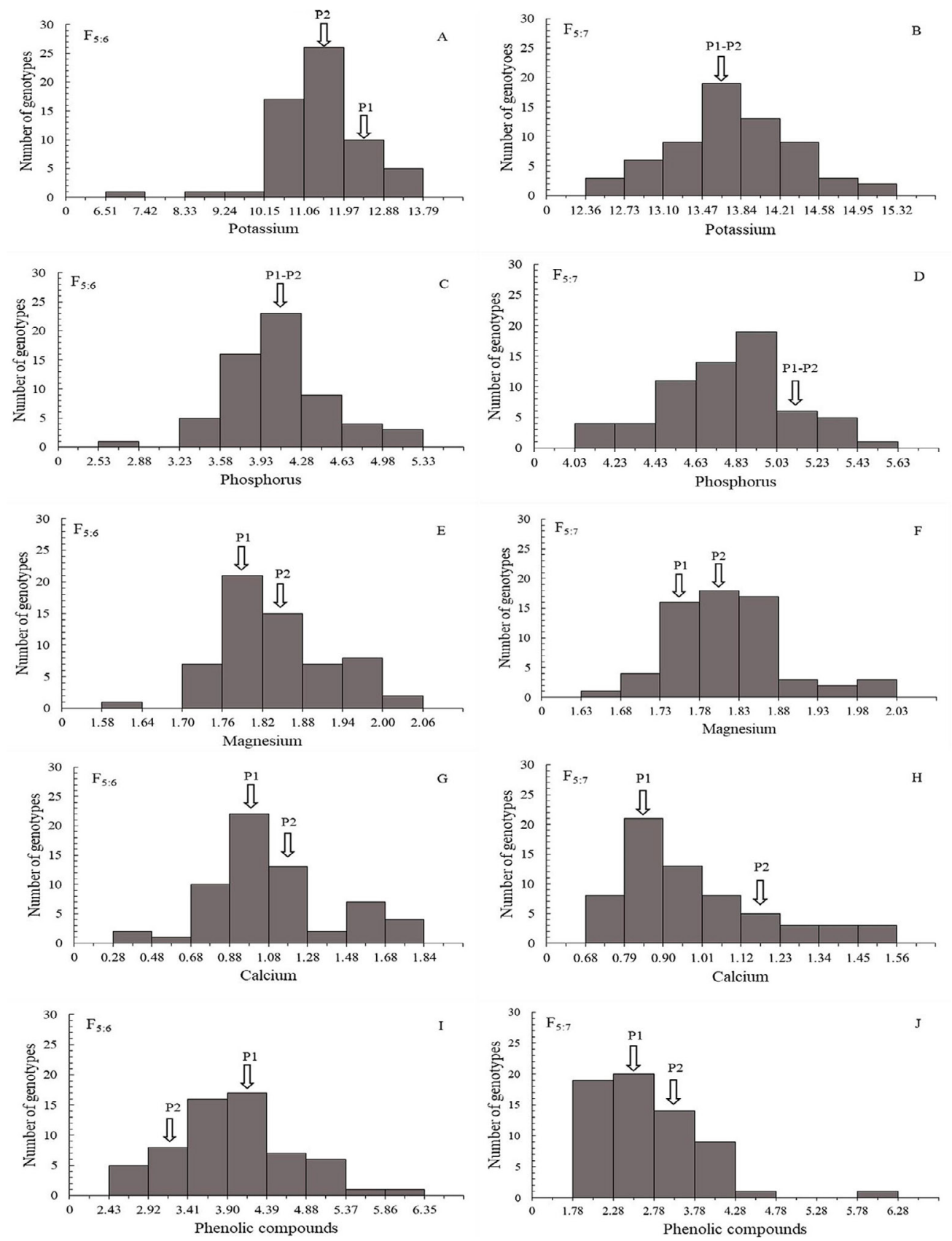

Figure 1: Frequency distribution histograms for the concentrations of potassium ( $\mathrm{g} \mathrm{kg}^{-1}$ dry matter - DM), phosphorus ( $\left.\mathrm{g} \mathrm{kg}^{-1} \mathrm{DM}\right)$, magnesium ( $\left.\mathrm{g} \mathrm{kg}^{-1} \mathrm{DM}\right)$, calcium ( $\left.\mathrm{g} \mathrm{kg}^{-1} \mathrm{DM}\right)$, and phenolic compounds (mg of gallic acid equivalent per $g$ of DM) obtained in the Andean common bean lines in the $F_{5: 6}$ and $F_{5: 7}$ generations. P1 and P2 are the parentes cultivars: P1 (Hooter) and P2 (Cal 96). 
Traits of quantitative inheritance are governed by many genes, in addition to being highly affected by the environment, and presenting continuous distribution. For these reasons, selection based on these traits is difficult. In the present study, although convergent parents were used in the cross, great variation was observed for the macromineral and phenolic compound concentrations across the Andean common bean lines. However, when cultivars Hooter and Cal 96 were previously selected by the breeding program, they were contrasting in the $\mathrm{K}$ and $\mathrm{Ca}$ concentrations in the grains (Ribeiro et al., 2014b). In this case, the differences in the amount of rainfall, minimum and maximum temperatures, and relative humidy during the growing seasons explain the variation that was observed for the macromineral and phenolic compound concentrations.

Macromineral concentration in common bean varies according to genotype, environment, and genotype $\times$ environment interaction (Hossain et al., 2013), and this was also observed for the phenolic compound concentration in common bean (García-Díaz et al., 2018). For this reason, identifying quantitative trait loci (QTL) associated with the mineral and phenolic compound concentrations can contribute to improving the efficiency of classical breeding programs. Blair et al. (2016) found three QTL associated with the $\mathrm{P}$ and $\mathrm{Mg}$ concentrations; two QTL associated with the $\mathrm{K}$ concentration; and one QTL associated with the $\mathrm{Ca}$ concentration in inbred lines in the $\mathrm{F}_{9: 11}$ generation obtained from a cross between Andean and Mesoamerican bean lines, which enabled molecular marker-assisted selection.

Andean common bean lines were generated with macromineral and phenolic compound concentrations lower and higher than the values observed in the parents, characterizing transgressive segregation. Blair et al. (2009) also observed transgressive segregation in the $\mathrm{F}_{5: 8}$ generation after crossing Andean and Mesoamerican parents with little variation in the $\mathrm{P}$ concentration. Transgressive segregation can be explained by epistasis, and recombinant events might generate new genotypes, resulting in genotypes different from their parents (Casañas et al., 2013). In the present study, we obtained Andean common bean lines with high macromineral concentration and with phenolic compound values lower and higher than those of their parents, which allows for the selection of lines with nutritional and functional properties.

\section{Selection of Andean common bean lines with nutritional properties}

When the goal of a breeding program is the development of common bean cultivars for human nutrition, the selected lines should possess high concentrations of $\mathrm{K}$, $\mathrm{P}, \mathrm{Mg}$, and $\mathrm{Ca}$ and low phenolic compound concentration. This is because the phenolic compounds may act as an anti-nutritional factor, reducing the digestion of the bean in humans (Ganesan; Xu, 2017). Genetic gain in a favorable way to the objectives of selection for nutritional properties was obtained for all traits: K (1.29\%), P (1.43\%), Mg (2.08\%), $\mathrm{Ca}(12.70 \%)$, and phenolic compounds (-3.68\%) (Table 2$)$.

The use of the rank sum index allowed the selection of the 13 superior genotypes for all evaluated traits. All selected genotypes exhibited a high $\mathrm{K}$ concentration, which was defined as $\geq 12.00 \mathrm{~g} \mathrm{~kg}^{-1} \mathrm{DM}$ for common bean by Steckling et al. (2017). However, only the lines DFA 33-18, DFA44-18, DFA 34-18, DFA 46-18, and DFA 36-18 also showed high P concentration, i.e., $\geq 5.00 \mathrm{~g} \mathrm{~kg}^{-1} \mathrm{DM}$, according to Steckling et al. (2017). The development of common bean lines with high $\mathrm{K}$ and $\mathrm{P}$ concentrations provides benefits to nutrition, since $\mathrm{K}$ participates in the reduction of blood pressure, lowering the risks of hypertension (Ekmekciouglu et al., 2016), while P is involved in cellular production of adenosine triphosphate (ATP), contributing to the maintenance of bones and teeth (Pravst, 2011).

For $\mathrm{Mg}$ in common bean, no proposal of stratification into classes has been found in the literature. However, considering the range of variation previously described for the $\mathrm{Mg}$ concentration in Mesoamerican and Andean common bean lines (Silva et al., 2012; Casañas et al., 2013; McClean et al., 2017; Ribeiro; Mezzomo; dos Santos, 2019), a high $\mathrm{Mg}$ concentration may be suggested as $\geq 2.00 \mathrm{~g} \mathrm{~kg}^{-1} \mathrm{DM}$. Only the cultivars Pérola and IPR Siriri showed high $\mathrm{Mg}$ concentration. Whereas the cultivars Pérola and IPR Tangará and the line DFA 46-18 exhibited high Ca concentration, i.e., $\geq 1.40 \mathrm{~g} \mathrm{~kg}^{-1} \mathrm{DM}$ (Ribeiro et al., 2013). The selection of common bean lines with high $\mathrm{Mg}$ and $\mathrm{Ca}$ concentrations is important for human nutrition. Mg plays an important role in the prevention of diabetes and cardiovascular disease (Alawi; Majoni; Falhammar, 2018), whereas $\mathrm{Ca}$ is necessary for bone formation and maintenance, preventing fractures and osteoporosis (Wimalawansa; Razzaque; Al-Daghri, 2018).

The lines DFA 34-18 and DFA 46-18 showed the lowest phenolic compound values, i.e., $\leq 1.97 \mathrm{mg} \mathrm{GAE}$ $\mathrm{g}^{-1} \mathrm{DM}$, which corresponds to an intermediate phenolic compound concentration, according to the classes established by Marathe et al. (2011). The development of common bean cultivars with lower phenolic compound concentration and higher macromineral concentration is important for inclusion in the diet of people who consume mostly cereals and legumes, for either economic or ideological reasons, and are thus more prone to developing symptoms of mineral deficiency. For those cases, including the lines DFA 34-18 (high K and P concentrations) and DFA 46-18 (high concentrations of $\mathrm{K}, \mathrm{P}$, and $\mathrm{Ca}$ ) in three or more meals weekly can contribute to improving their nutrition as a result of decreased phenolic compound concentration. 
Table 2: Mean of the original population (Xo), mean of the selected population $(X s)$, heritability $\left(h^{2}\right)$, genetic gain (GG), and percentage of genetic gain (GG, \%) with simultaneous selection by the rank sum index for the 13 Andean common bean lines ( $20 \%$ of the total lines evaluated) with high concentrations of potassium ( $\mathrm{g} \mathrm{kg}^{-1}$ of dry matter - DM), phosphorus ( $\left.\mathrm{g} \mathrm{kg}^{-1} \mathrm{DM}\right)$, magnesium ( $\left.\mathrm{g} \mathrm{kg}^{-1} \mathrm{DM}\right)$, and calcium ( $\mathrm{g} \mathrm{kg}^{-1} \mathrm{DM}$ ) and low phenolic compounds (phenolic, mg of gallic acid equivalent per $\mathrm{g}$ of $\mathrm{DM}$ ) in the $\mathrm{F}_{5: 7}$ generation.

\begin{tabular}{|c|c|c|c|c|c|}
\hline & Xo & Xs & $\mathrm{h}^{2}$ & GG & GG (\%) \\
\hline Potassium & 13.79 & 14.17 & 45.71 & 0.18 & 1.29 \\
\hline Phosphorus & 4.77 & 4.93 & 43.15 & 0.07 & 1.43 \\
\hline Magnesium & 1.81 & 1.86 & 69.01 & 0.04 & 2.08 \\
\hline Calcium & 0.97 & 1.11 & 85.67 & 0.12 & 12.70 \\
\hline Phenolic & 2.78 & 2.63 & 70.51 & -0.10 & -3.68 \\
\hline \multirow[t]{2}{*}{ Total gain } & & & & 0.30 & 13.82 \\
\hline & ---------------- & ----------------------' & 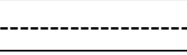 & -------- & \\
\hline Genotype & Potassium & Phosphorus & Magnesium & Calcium & Phenolic \\
\hline Pérola & 14.35 & 4.75 & 2.00 & 1.46 & 3.38 \\
\hline DFA 21-18 & 14.14 & 4.86 & 1.88 & 0.97 & 2.06 \\
\hline DFA 33-18 & 14.88 & 5.12 & 1.85 & 0.80 & 2.27 \\
\hline DFA 44-18 & 13.62 & 5.12 & 1.85 & 1.05 & 2.26 \\
\hline DFA 34-18 & 13.20 & 5.26 & 1.86 & 1.10 & 1.97 \\
\hline DFA 40-18 & 15.30 & 4.67 & 1.83 & 1.15 & 2.37 \\
\hline DFA 45-18 & 13.83 & 4.99 & 1.84 & 0.94 & 2.42 \\
\hline IPR Tangará & 13.51 & 4.89 & 1.94 & 1.47 & 3.78 \\
\hline IPR Siriri & 14.35 & 4.44 & 2.01 & 1.28 & 4.07 \\
\hline DFA 46-18 & 13.62 & 5.12 & 1.75 & 1.44 & 1.95 \\
\hline DFA 36-18 & 14.25 & 5.10 & 1.84 & 0.79 & 2.54 \\
\hline DFA 47-18 & 14.14 & 4.94 & 1.76 & 1.15 & 2.56 \\
\hline DFA 17-18 & 15.09 & 4.87 & 1.83 & 0.84 & 2.61 \\
\hline
\end{tabular}

Selection of Andean common bean lines with nutritional and functional properties

If the goal of a breeding program is to develop common bean cultivars with nutritional and functional properties, lines with high concentrations of $\mathrm{K}, \mathrm{P}, \mathrm{Mg}$, $\mathrm{Ca}$, and phenolic compounds must be selected. In this case, higher amounts of phenolic compounds in the diet have several health promoting effects (Doria et al., 2012; Chávez-Mendoza; Sánchez, 2017; Ganesan; Xu, 2017). Genetic gain in a favorable way to the objectives of selection for nutritional and functional properties was obtained for $\mathrm{K}(0.45 \%), \mathrm{Mg}(3.10 \%)$, Ca (13.18\%), and phenolic compounds $(24.22 \%)$ (Table 3$)$.

Direct selection was applied for phenolic compounds, and the weights attributed to $\mathrm{K}, \mathrm{Mg}, \mathrm{Ca}$, and phenolic compounds were different in the selection of common bean lines for nutrition and health, changing the relationships among the selected lines. This resulted in the selection of 13 genotypes of Andean common bean with high $\mathrm{K}$ concentration. The lines DFA 04-18 and DFA 05-18 also have high P concentration, whereas the cultivars Pérola, IPR Siriri, and IAC Imperador exhibited high Mg concentration. Pérola and IPR Tangará were the cultivars with the highest $\mathrm{Ca}$ concentration. Previous studies have shown a wide variation in mineral concentrations in different grain types of common bean genotypes cultivated in Brazil (Santos et al., 2010) and in EUA (McClean et al., 2017). When the nutritional composition of the different common bean cultivars that can be used in nutrition is known, it is possible to formulate diets that meet the different nutritional requirements of consumers. This constitutes an important innovation in terms of health benefits. 
Table 3: Mean of the original population (Xo), mean of the selected population $(X s)$, heritability $\left(h^{2}\right)$, genetic gain (GG), and percentage of genetic gain (GG, \%) with simultaneous selection by the rank sum index for the 13 Andean common bean lines ( $20 \%$ of the total lines evaluated) with high concentrations of potassium ( $\mathrm{g} \mathrm{kg}^{-1} \mathrm{of}^{-1}$ dry matter - DM), phosphorus ( $\left.\mathrm{kg}^{-1} \mathrm{DM}\right)$, magnesium ( $\left.\mathrm{g} \mathrm{kg}^{-1} \mathrm{DM}\right)$, calcium ( $\left.\mathrm{g} \mathrm{kg}^{-1} \mathrm{DM}\right)$, and phenolic compounds (phenolic, $\mathrm{mg}$ of gallic acid equivalent per $\mathrm{g}$ of $\mathrm{DM}$ ) in the $\mathrm{F}_{5: 7}$ generation.

\begin{tabular}{cccccc}
\hline & Xo & Xs & $h^{2}$ & GG & GG (\%) \\
\hline Potassium & 13.79 & 13.92 & 45.71 & 0.06 & 0.45 \\
Phosphorus & 4.77 & 4.77 & 43.15 & -0.00 & -0.01 \\
Magnesium & 1.81 & 1.89 & 69.01 & 0.06 & 3.10 \\
Calcium & 0.97 & 1.12 & 85.67 & 0.13 & 13.18 \\
Phenolic & 2.78 & 3.73 & 70.51 & 0.67 & 24.22 \\
Total gain & & & & 0.92 & 40.94 \\
\hline & ------------------------------------------------------------- & \\
\hline Genotype & Potassium & Phosphorus & Magnesium & Calcium & Phenolic \\
Pérola & 14.35 & 4.75 & 2.00 & 1.46 & 3.38 \\
IPR Tangará & 13.51 & 4.89 & 1.94 & 1.47 & 3.78 \\
Carioca & 14.14 & 4.45 & 1.96 & 1.38 & 4.27 \\
IPR Siriri & 14.35 & 4.44 & 2.01 & 1.28 & 4.07 \\
Fepagro Garapiá & 13.62 & 4.87 & 1.87 & 1.07 & 3.25 \\
BRS Estilo & 13.20 & 4.87 & 1.84 & 1.30 & 4.05 \\
DFA 04-18 & 14.14 & 5.28 & 1.78 & 0.80 & 3.13 \\
SCS 205 Riqueza & 14.25 & 4.40 & 1.91 & 1.01 & 5.81 \\
DFA 23-18 & 13.93 & 4.70 & 1.84 & 0.90 & 4.13 \\
IAC Imperador & 13.83 & 4.39 & 2.00 & 1.24 & 4.09 \\
DFA 05-18 & 14.04 & 5.12 & 1.81 & 0.69 & 2.92 \\
Cal 96 & 13.72 & 4.90 & 1.78 & 1.12 & 2.85 \\
DFA 35-18 & 13.93 & 4.99 & 1.85 & 0.79 & 2.80 \\
\hline
\end{tabular}

All the selected genotypes have high phenolic compound concentration ( $\geq 2.0 \mathrm{mg} \mathrm{GAE} \mathrm{g}^{-1} \mathrm{DM}$ ), as defined previously by Marathe et al. (2011). Dietary use of common bean genotypes with high phenolic compound concentration presents health promoting benefits, including anti-oxidant, anti-diabetic, anti-obesity, anticarcinogenic, anti-mutagenic, anti-inflammatory, and cardioprotective effects (Chávez-Mendoza; Sánchez, 2017; Ganesan; Xu, 2017). These characteristics confer functional properties to common bean.

Dietary inclusion of common bean cultivars with high concentrations of $\mathrm{K}, \mathrm{P}, \mathrm{Mg} \mathrm{Ca}$, and phenolic compounds is indicated for people with access to balanced diets containing a variety of plant-and animalderived products, in which the bean can be used with nutritional and functional purposes. In this case, the use of genotypes DFA 04-18, DFA 05-18, Pérola, IPR Siriri, IAC Imperador, and IPR Tangará is indicated due to their high concentrations of two or more macrominerals and of phenolic compounds.

\section{CONCLUSIONS}

The concentrations of $\mathrm{K}, \mathrm{P}, \mathrm{Mg}, \mathrm{Ca}$, and phenolic compounds show intermediate to high heritability $\left(h^{2}: 43.15\right.$ to $\left.98.85 \%\right)$, transgressive segregation, and quantitative inheritance in the recombinant inbred line population of Andean beans. The lines DFA 34-18 and DFA 46-18 have high $\mathrm{K}$ and $\mathrm{P}$ concentrations and low phenolic compound concentration and will be selected for human nutrition. The lines DFA 04-18 and DFA 05-18 and the cultivars Pérola, IPR Siriri, IAC Imperador, and IPR Tangará have high concentrations of two or more 
macrominerals and phenolic compounds, i.e., they have nutritional and functional properties and will be selected by the breeding program.

\section{ACKNOWLEDGEMENTS}

To the National Council for Scientific and Technological and Development (CNPq) for financial support and scholarships. To the Coordination for the Improvement of Higher Education Personnel (CAPES) for the grants awarded.

\section{REFERENCES}

ALAWI, A. M. A. L.; MAJONI, S. W.; FALHAMMAR, H. Magnesium and human health: Perspectives and research directions. International Journal of Endocrinology, 2018:1-17, 2018.

BLAIR, M. W. et al. Quantitative trait locus analysis of seed phosphorus and seed phytate content in a recombinant inbred line population of common bean. Crop Science, 49(1):237-246, 2009.

BLAIR, M. W. et al. Inheritance of seed phytate and phosphorus levels in common bean (Phaseolus vulgaris L.) and association with newly-mapped candidate genes. Molecular Breeding, 30(3):1265-1277, 2012.

BLAIR, M. W. et al. Genetic dissection of ICP-detected nutrient accumulation in the whole seed of common bean (Phaseolus vulgaris L.). Frontiers in Plant Science, 7:1-9, 2016.

CASAÑAS, F. et al. Mapping of QTL associated with seed chemical content in a RIL population of common bean (Phaseolus vulgaris L.). Euphytica, 192(2):279-288, 2013.

CHÁVEZ-MENDOZA, C.; SÁNCHEZ, V. Bioactive compounds from Mexican varieties of common bean (Phaseolus vulgaris): Implications for health. Molecules, 22(8):1-32, 2017.

COMISSÃO TÉCNICA SUL BRASILEIRA DE FEIJÃO - CTSBF. Informações técnicas para o cultivo de feijão na Região Sul brasileira 2012. Florianópolis: Empresa de Pesquisa Agropecuária e Extensão Rural de Santa Catarina, 2012. 157p.

CRUZ, C. D. Genes Software - Extended and integrated with the R, Matlab and Selegen. Acta Scientiarum.Agronomy, 38(4):547-552, 2016.

DORIA, E. et al. Anti-nutrient components and metabolites with health implications in seeds of 10 common bean (Phaseolus vulgaris L. and Phaseolus lunatus L.) landraces cultivated in Southern Italy. Journal of Food Composition and Analysis, 26(1-2):72-80, 2012.
EKMEKCIOGLU, C. et al. The role of dietary potassium in hypertension and diabetes. Journal of Physiology and Biochemistry, 72:93-106, 2016.

FERRARI, S.; RAMOS JÚNIOR, E. U. Tipos especiais de feijão. In: ARF, O. et al. Aspectos gerais da cultura do feijão, Phaseolus vulgaris L. Botucatu: Fundação de Estudos e Pesquisas Agrícolas e Florestais, 2015. p.371-386.

GANESAN, K.; XU. B. Polyphenol-rich dry common beans (Phaseolus vulgaris L.) and their healths benefits. International Journal of Molecular Sciences, 18(2331):126, 2017.

GARCIA-DÍAZ, Y. D. et al. Bioactive compounds and antioxidant activity in the common bean are influenced by cropping season and genotype. Chilean Journal of Agricultural Research, 78(2):255-265, 2018.

HOSSAIN, K. G. et al. Interdependence of genotype and growing site on seed mineral compositions in common bean. Asian Journal of Plant Sciences, 12(1):11-20, 2013.

JOST, E. et al. Comparison among direct, indirect and index selections on agronomic traits and nutritional quality traits in common bean. Journal of the Science of Food and Agriculture, 93(5):1097-1104, 2013.

KATUURAMU, D. N. et al. Genome-wide association analysis of nutritional composition-related traits and iron bioavailability in cooked dry beans (Phaseolus vulgaris L.). Molecular Breeding, 38:1-18, 2018.

KUINCHTNER, A.; BURIOL, G. A. Clima do Estado do Rio Grande do Sul segundo a classificação climática de Köppen e Thornthwaite. Disciplinary Science, 2(1):171-182, 2001.

MARATHE, S. A. et al. Comparative study on antioxidant activity of different varieties of commonly consumed legumes in India. Food and Chemical Toxicology, 49(9):2005-2012, 2011.

MAZIERO, S. M.; RIBEIRO, N. D.; FACCO, H. S. Genetic parameters of agronomic and nutritional traits of common bean (Phaseolus vulgaris L.) population with biofortified grains. Australian Journal of Crop Science, 10(6):824-830, 2016.

MCCLEAN, P. E. et al. Phenotypic diversity for seed mineral concentration in North American dry bean germplasm of Middle American ancestry. Crop Science, 57:3129-3144, 2017.

MIYAZAWA, M. et al. Análise química de tecido vegetal. In: SILVA, F. C. Manual de análises químicas de solos, plantas e fertilizantes, 2nd edn. Brasília: Embrapa Informação Tecnológica, 2009. p.191-234. 
MULAMBA, N. N.; MOCK, J. J. Improvement of yield potential of the Eto Blanco maize (Zea mays L.) population by breeding for plant traits. Egyptian Journal of Genetics and Cytology, 7(1):40-51, 1978.

PRAVST, I. Risking public health by approving some health claims? The case of phosphorus. Food Policy, 36(5):726728, 2011.

RAMALhO, M. A. P.; FERREIRA, D. F.; OliVEIRA, A. C. de. Experimentação em genética e melhoramento de plantas. Lavras: Editora UFLA, 2000. 326p.

RESENDE, M. D. V. de; DUARTE, J. B. Precision and quality control in variety trials. Pesquisa Agropecuária Tropical, 37(3):182-194, 2007.

RIBEIRO, N. D. et al. Selection of common bean lines with high agronomic performance and high calcium and iron concentrations. Pesquisa Agropecuária Brasileira, 48(10):1368-1375, 2013.

RIBEIRO, N. D. et al. Agronomic performance and cooking quality of special-grain beans lines. Revista Ciência Agronômica, 45(1):92-100, 2014a.

RIBEIRO, N. D. et al. Evaluation of special grains bean lines for grain yield, cooking time and mineral concentration. Crop Breeding and Applied Biotecnology, 14(1):15-22, $2014 \mathrm{~b}$.

RIBEIRO, N. D.; MEZZOMO, H. C.; SANTOS, G. G. dos. Genetic parameters and combined selection for seed coat color and macrominerals in Mesoamerican common bean lines. Genetics and Molecular Research, 18(2):1-14, 2019.

RIBEIRO, N. D. et al. Genetic parameters and combined selection for phosphorus, phytate, iron, and zinc in Mesoamerican common bean lines. Ciência e Agrotecnologia, 43:e027818, 2019.
SANTOS, H. G. dos et al. Sistema brasileiro de classificação de solos. 5. ed. Brasília: Embrapa Solos, 2018. 356p.

SANTOS, S. C. et al. Multivariate characterization of bean varieties according to yield production, mineral and phenolic contents. Journal of the Brazilian Chemical Society, 21(10):1917-1922, 2010.

SILVA, C. A. et al. Chemical composition as related to seed color of common bean. Crop Breeding and Applied Biotechnology, 12(2):132-137, 2012.

SINGLETON, V. L.; ROSSI JUNIOR, J. A. Colorimetry of total phenolics with phosphomolybdic-phosphotungstic acid reagents. American Journal of Enology and Viticulture, 16(3):144-158, 1965.

SOLTANI, A. et al. Targeted analysis of dry bean growth habit: Interrelations among architectural, phenological, and yield components. Crop Science, 56(6):3005-3015, 2016.

STECKLING, S. M. de. et al. Genetic diversity and selection of common bean lines based on technological quality and biofortification. Genetics and Molecular Research, 16(1):1-13. 2017.

VENCOVSKY, R.; BARRIGA, P. Genética biométrica no fitomelhoramento. Ribeirão Preto: Revista Brasileira de Genética, 1992. 496p.

WIMALAWANSA, S. J.; RAZZAQUE, M. S.; AI-DAGHRI, N. M. Calcium and vitamin $D$ in human health: Hype or real?. Journal of Steroid Biochemistry and Molecular Biology, 180:4-14, 2018.

ZILIO, M.; SOUZA, C. A.; COELHO, C. M. M. Phenotypic diversity of nutrientes and anti-nutrients in bean grains grown in different locations. Revista Brasileira de Ciências Agrárias, 12(4):528-534, 2017. 